\title{
НЕМОГУЋИ, ТРОМПЛЕЈСКИ ЧИТАЛАЦ И ЊЕГОВИ РОЂАЦИ
}

Апстракт: У раду се полази од студије Мери-Лор Рајан Нарайив

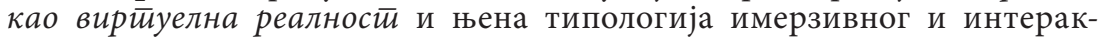
тивног читаоца хипертекста допуњује антиципацијом хипотетичког тромплејског читаоца. Он се објашњава поређењем по сличностима и разликама у односу на зависног читаоца који често подлеже референцијалним или афективним заблудама. Други тип диференцијације се успоставља у односу на лудички концепт читаоца актуелног у виртуелном свету електронских медија. Рад је једна врста генезе која прати читаоце од концептуализација њихових заблуда (синдром Дон Кихот, Ема Бовари), преко читалаца који постају главни јунаци постмодернистичке прозе (Кортасар, Борхес, Павић, Петровић) до антиципација нових читалаца (хипер)текста који у њему нестају.

Кључне речи: тромплеј, читалац, имерзија, интерактиван читалац, зависан читалац

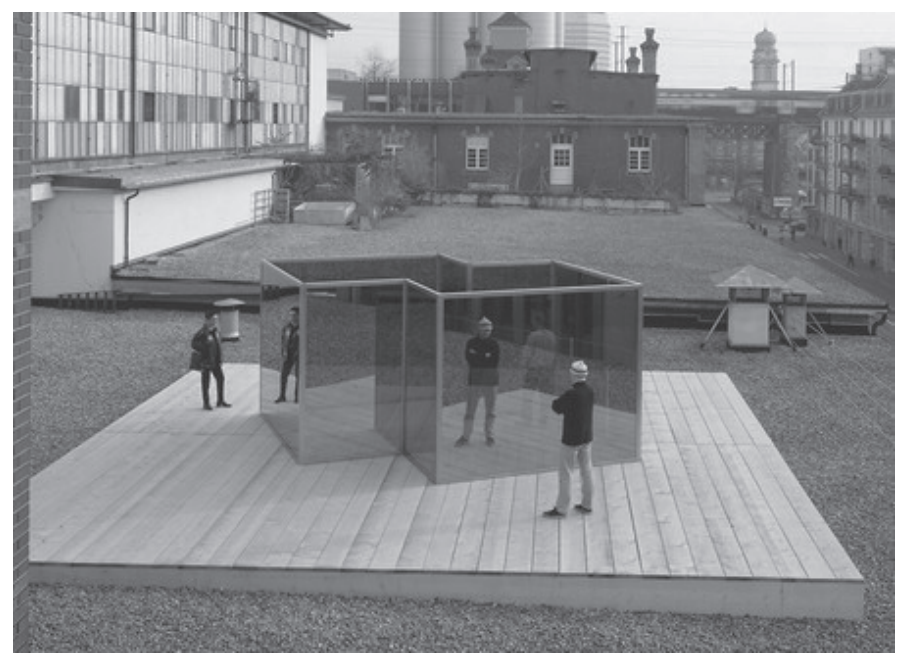

Rooftop Urban Park Project/Two-Way Mirror Cylinder Inside Cube, by Dan Graham $(1991)^{1}$

1 Dan Graham, Two Joined Cubes, 1997 Two-way mirror glass, aluminum and perforated steel $90 \mathrm{x}$ 90 x 57.5 cm / 35 2/5 x 35 2/5 x 22 4/5 in @ Dan Graham / Photo: A. Burger (photo courtesy of: http:// www.hauserwirth.com) Преузето са саjта: https://farticulate.wordpress.com/2010/12/14/14-december-2010-dan-graham-selected-sculptures-interview/, 26. 06.2020. 
У необичној инсталацији Дена Грејама (Dan Graham) Два оїлеgавань унуйар коике (Two-Way Mirror Cylinder Inside Cube) посматрачи коцке истовремено имају утисак да су ван и унутар ње, да сами себе посматрају из две стајне позиције. Ова оптичка варка тела $y$ коцки и тела ван коцке, погледа $y$ и погледа из, визуелна је метафора читалаца о којима ћемо писати.

Како главни јунак нашег рада, производ маште, тромплејски читалац, заувек остаје у коцки (у тексту, у свету фикцијских јунака), његова атрибуција биће у знаку негација - препознавања сличности и разлика у односу на његове, могуће, у теоријама књижевности препознате и описане рођаке. У нашем раду прећи ће пут од негација и метафора до футуристичких пројекција. На рођачкој листи су се нашли читаоци с валидном теоријском основом: имерзиван читалац и његова варијација посвећен читалац, интерактиван читалац и његове варијације, постмодерни читалац и читалац хипертекста, лудички читалац.

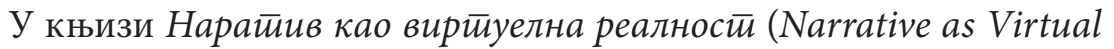

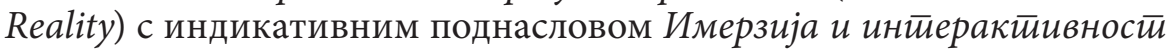
у књижевностии и елекитронским меgијима (Immersion and Interactivity in Literature and Electronic Media) Мери-Лор Рајан (Marie-Laure Ryan), наш водич кроз светове ангажованих читалаца, издваја два типа читања, сходно томе и два типа поетика - обележава их као имерзивно читање (имерзивна поетика) и интерактивно читање (поетика интерактивног текста). Имерзија или урањање подразумева привидну пасивизацију читаоца пред сугестивном и перцептибилно имагинативном моћи наративног света, самозаборав и задовољство уживљавања, урањања у наративни свет. Интерактивно читање, насупрот томе, подразумева освешћену активну позицију читаоца који учествује у заплетима и расплетима приче, избору наративних опција (у електронском тексту ове могућности се умножавају).

Појам имерзивно читање уклапа се у „водене метафоре“ којима Рајанова сликовито објашњава конструкцију виртуелне реалности. Диференцирајући три врсте имерзије (просторну, временску и емоционалну), она раздваја текстове који пружају већи или мањи отпор имерзивном напору читаоца: „У најбољем случају, урањање може бити авантуристичко и окрепљујуће искуство упоредиво са пливањем у хладном океану на моћном сурфу. На почетку, окружење се чини непријатељско, улазите у воду невољно, али када се поквасите и поверите своје тело таласима, не пожелите да их икада напустите“ (Рајан 2001:11). Уколико отпор изостане и читалац брзо и лако „урони“ у свет фикције, апсорптивни потенцијал текста није нужно предуслов његове естетске валидности јер се естетска вредност не може редуковати само на имерзивни интензитет. „Изгубити се у фикцији“, пише један од раних теоретичара хипертекста Џеј Дејвид Болтер (Jay David Bolter), „циљ је наивног читатеља 
или онога који чита да се забави. Нарочито је то карактеристика жанровске фантастике, попут романтике или научне фантастике“ (Bolter 1991: 155; Рајан 2001: 11).

Ангажовање читаоца у конкретизацији (актуелизацији) наративног света, 'маштовити однос према текстуалном свету' зависи колико од апсорптивног потенцијала текстуалне стварности, толико и од диспозиција самог читаоца. Реалистички и сентименталистички текстови подразумевају већи степен уживљавања. Они рачунају на емотивну партиципацију (рецепција Гетеовог Верйера), на консензус значења (рецепција Балзака). Постмодерна књижевност, насупрот томе, рачуна на (ауто)рефлексију - метакоментар у коме се читалац разобличава као читалац, а текст као текст. На пример, на лествици на којој су маркирани подеоци за јачину читања, добар реалистички роман добија највећу оцену за имерзивно читање, постмодерни, особито у форми хипертекста - за интерактивно. На једном полу нашли би се Лаза Лазаревић и Симо Матавуљ, а на другом Милорад Павић и Горан Петровић. ${ }^{2}$

Ми се нећемо бавити типом текста и његовим комбинаторним (нпр. речничком структуром Хазарскої речника) или апсорпцијским потенцијалом (развијеним описима, у Лазаревићевој приповеци

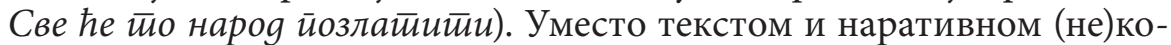
херентношћу света у који се улази и из којег сви (сем тромплејског читаоца) излазе, бавићемо се његовим посетиоцима - читаоцима путницима.

Тромплејски читалац којим ћемо самеравати остале, у литератури већ описане читаоце, ${ }^{3}$ наш је конструкт. ${ }^{4}$ Сврставамо га у галерију јунака које одликује бивалентни онтолошки статус; такви јунаци су живи мртваци (вампири), неживе ствари а оживела бића (нпр. оживеле статуе или оживели портрети). У нашим уводним примерима, тромплејски читалац је фикционализован читалац; он

2 У овој поларизацији треба избећи искључивости јер и класичан „линеаран“ текст се не чита само линеарно.

3 У српској науци најподробније синтезе и теоријска типолошка разврставања читалаца пронашли смо у радовима Мирјане Д. Бојанић Ћирковић написаним по одбрањеној докторској дисертацији: Тийолоіија чийалаца у романима Милораgа Па-

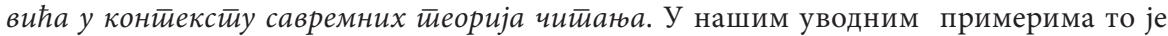
читалац иманентан тексту, у завршним - враћамо га у тело реалног, али хипотетички реалног читаоца.

4 Тромплеј је трик, оптичка варка којом се ствара илузија тродимензионалних објеката на дводимензионалној површини. Нашу пажњу није привукла ни техника која ствара илузију ни несавршеност чула вида које омогућава превару. У нашој номинализацији тромплејских бића изворно значење речи везано за превару ока преусмерили смо ка ефекту те преваре. Заправо превару ока проширили смо на превару чула, смисла, значења... Књижевним манифестацијама онтолошки бивалентних бића (тромплејски читалац биће једна од манифестација) посветили смо будућу монографију задржавши одомаћен неологизам, тромплеј, свесни његовог суженог значења (превара ока (trompe-l’œil) наспрам превара свих чула: trompe-fiction, trompe-les-sens). 
је књижевни јунак који чита и из своје стварности улази у текст који чита или текстуалну стварност оживљава у свом стварносном наративном универзуму. Унутар текстуалне стварности позицониран је у различитим некомпатибилним световима (могућ у немогућем свету, немогућ у могућем свету). У наставку раду придаћемо му двоструки статус. С његове литераризације (с текстова у којима се фикцијским читаоцима унутар наративног света придаје тромоплејски статус, тј. бивалентно онтолошко стање), прећи ћемо на реалног читаоца, нарочито оног који се приближава дигиталним бићима и све више урања у хипертекстуалну реалност. У нашој интерпретацији, добро познати читалац који је у пољу фикције маркиран као превара, обмана, лаж, заблуда, направиће искорак у футуристичку реалност, у поље хипотетичке електронске стварности будућих киборга; направиће тромплејски скок од читаоца иманентог тексту ка читаоцу који је хипотетички реалан.

\section{Тромплејски versus посвећени читалац}

Први рођак нашег тромплејског читаоца је зависни читалац.

У теоријама књижевности наводи се као пример погрешног читаоца, оног који је превише уронио у текст. На скали која мери различите начине апсорпције света - он припада четвртом типу. Рајнова пише о: 1. концентрисаном читаоцу 2. читаоцу с јаким имагинарним учешћем, 3. занесеном и 4. зависном читаоцу - синдром Дон Кихота. Мера имерзије расте према последњем у низу (Concentration $\rightarrow$ Imaginativeinvolvement $\rightarrow$ Entrancement $\rightarrow$ Addiction) (Рајан 2001: 99).

Зависни читалац „нестаје“ у тексту на два начина:

- у урвом случају читање је ескапистички чин;

- у другом, реч је о „губитку способности да се разликују текстуални светови, нарочито они из фикције, од стварног света“"(Рајан 2001 :9) Рајанова следи Јаусову класификацију у којој се на негативном полу читалаца који имају адмиративан однос према тексту налазе читаоци имитатори и ескаписти (Jаус, 1978).

Читалац који је поверовао у причу и заборавио да је текст „само текст“, од Дон Кихота преко Еме Бовари и њихових транстекстуалних двојника, не престаје да инспирише и ауторе фикцијских светова и њихове аналитичаре. На оси имерзије, с једне стране су Неверне Томе, ${ }^{5}$ неповерљиви и сумњичави, а с друге, предани „посвећени читаоци“ који брзо и лако склапају „миметички уговор“.

5 У приповеци Јована Грчића Миленка У Гостиионици Код полузвезде на именgан

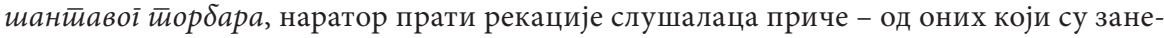
ти и не трпе њено прекидање, до оних који је својим неповерењем прекидају. Једног од њих „зато што ништа не верује“, наратор назива „Неверни Тома“ (Грчић, б.г. 340). 
Како изгледа „судар“ два начина рецепције приче можемо видети у дијалогу између две читатељке у Сремчевом роману Пой Ћира u $\bar{u} о \bar{u}$ Сйupa, која свака за себе представља прекорачење мере и једну од крајности читања: једна болује од синдрома референцијалне илузије („замењујућу представу о стварности самом стварношћу“ Рифатер 1990: 197) $)^{6}$, а друга од афективне заблуде.

А) референцијална заблуда и текст као „болесна фантазија“

Сидино читање:

Е, кад би то било истина! Него тек тако, ма ко... А ко је спис'о то? - рече гђа Сида бришући сузе.

- Написао је Коста Руварац.

- Коста! Та... то је поп-Васин Коста... поп Васа из Саса! Ex, шта ти велим ја! Откуд он зна то? Ја познајем три господар-Јове у Карловци, и ниједан није им’о ћер Драгињу. Све којешта! Макар није им’о друга посла. Е' тако! Поп Васа га шиље, и што кажу, откида од своји уст’а да му син штудира, па да временом буде од њега човек, а он - измишљава све којешта. Та да је сто пута труковано, не верујем ја у то (Подв. Д. В.; Сремац 2009: 126).

Другом типу грешке (афективна заблуда) најчешће подлежу љубитељи сентиментално-патетичне књижевности. У Сремчевом роману „чувствителни читалац“ који пати од „вертеровског синдрома" ${ }^{\text {“8 }}$ мета је пародије:

И мисли њене, и песме које је најрадије тада певала, и књиге које је читала - све је то доказивало да је Јули тежак живот, да јој нема живота и да јој је смрт била једина срећа (...)

- Ал' само још пола стране, па сам готова. Слушајте, слатка мамо!

И Јула поче гласно дршћућим гласом читати: „Љубинкове кости леже сад у јуначкој земљи херцеговачкој, ал гроба му не може нико наћи; но баш и да се знаде за њега, ко би му дошао у походе ко би над њим наричући сузе пролио, кад никога нема од свога?

Проливајте барем ви, драге сестре Српкиње, сузу жалости над несретним удесом нашег Љубинка... (Сремац 2009: 126).

У наведеним примерима губитак мере у читању увек је и губитак оријентације. Било да књижевном тексту приступају као трачу у

6 В. рад М. Рифатера, Референцијална илузија, Трећи програм, 85, 1990, 196-202.

7 У Јаусовој интерпретацији реч је о негативном полу позитивног етичног и емпатичног ангажмана читаоца - о ганутљивости, (само)сажаљевању (Jаус 1978: 434).

8 О рецепцији Гетеовог Вериетера у српској књижевности Милорад Павић је писао: „Да је оно тамо (мисли на Аустрију), као и другде у Европи имало обожаваоце и било једно од најпознатијих књижевних дела читаве епохе, показује и једна белешка из Пожунских новина која још 1775, одмах после изласка романа (1774), бележи: „... ко не познаје дирљиву историју сиротог Вертера? Ко није пролио сузе саучешћа над његовим гробом?“" (Павић 1976: 241) 
који треба или не треба да поверују или у њему виде непресушни извор емоција, Сремчеви погрешни читаоци су врло значајни за наш рад - они су примери прекомерја, а прекомерје је основно обележје тромплејског читаоца.

Пометен, дезоријентисан читалац, изгубљен у имерзивном прекомерју, био је идеалан јунак хумористичко-пародијске литературе, али и аутобиографских текстова у којима су се кроз њега филтрирале читалачке заблуде. Зависан (имерзиван) читалац је постао поетичко оруђе преко којег се утицало на рецепцијски хоризонт читалаца, сугерисало шта и како треба, тј. не треба да читају. Доситеј, на пример, пише о својој младалачкој залуђености, житијима, повестима из прилога:

Ја, напунивши моју главу детињску с казанијами и с пролози, а не будући нимало кадар сврх чеса либо како ваља мислити ни расуждавати, наумио сам био савршено да се посветим. Размишљајући шта су страдали мученици, ја би[x] тешко жалио што и сад не муче христјане, те бих се ja нама $[\mathrm{x}]$ дао за закон испећи; а кад би ми пало на ум шта су пустињаци радили и пословали, крепко би[x] желио да се намерим на ког пустињика да с њим одем у египетске и у арапске пустиње, гди нема стопе човека жива (Обрадовић 2009: 11).

Хумористичко-пародична и дидактичка литература профилисала је „прекомерног читаоца“ (зависног, посвећеног) као смешну или опасну грешку коју треба избећи. Наш немогући, тромплејски читалац нити је извор смеха нити је дидактички реквизит. Његово прекомерје је много опасније. Он не жели да његово „ронилачко“ искуство буде привремено, а његова зависност „контролисана“. Он није прекорачио меру урањања, он је без мере.

Да бисмо успоставили разлику између имерзивног читаоца (чак и кад се његово читање тумачи као погрешно) и тромплејског читаоца - прибегавамо контрастима.

Тромплејски читалац је негација читаоца, негација текста, негација естетике. Он је попут идеје у Бодријаревом (Jean Baudrillard) Пербекйном злочину (The Perfect Crime) која нестаје кад постане ултимативна, тј. кад нестане као идеја и постане ствар међу стварима; тако је тромплејски читалац оптимализована крајност која укида читаоца. Профил тромплејског читаоца помаља се у „негативној“ дескрипцији, у атрибуцији немогућег читаоца (опозита „могућем“):

1. За разлику од зависног читаоца који је профилисан као „грешка“ која се може исправити, тромплејски читалац нема могућност корекције. Потпуним урањањем у текст он чини читалачки salto mortale.

2. За разлику од имерзивног читаоца који прати радњу и емотивно партиципира с ликовима, у тромплејском читању читалац не „оживљава ликове“ већ живи с њима, он је за њих оживљен. 
3. Читање за њега престаје да буде изабрани привремни естетски догађај и постаје онтолошко догађање.

4. У тромплејском читању не постоје две појавности читаоца: она физичка у којој је његово тело и она ментална којом се пребацује у наративни свет; тромплејски читалац је попут вируса који мења онтолошки предзанак; он пролази кроз врата светова живих и неживих; он себе живи само у наративном свету.

5. У тромплејском читању потире се аутономност текста - медиј престаје да буде транспарентан јер нестаје; не постоји текст, само његов свет.

6. За тромплејског читаоца није примордијална наративна жеља спознаја краја приче јер је она истовремно и спознаја сопственог краја.

7. Тромплејски читалац није имерзиван. Он је инвазиван читалац. Ако следимо „водене“ метафоре Мери-Лор Рајан, то је читалац који је, за разлику од зависног читаоца, научио да дише без кисеоника. Он не урања већ продире у текст, и зато за њега користимо метафору инјекције (интрацитоплазматске инјекције којом се пробија ћелија света).

8. Инјектираност у нови свет је прекид - губитак моћи тромплејског читаоца да „упије“ наративни свет, да га кроз различите облике имерзивних активности (темпорална, спацијална, емотивна) запоседне ментално.

\section{Синдром двојника (шизофреност читаоца и његова идентификација с другим)}

Поред афективне заблуде, друга мера коју прекорачује имерзивни читалац односи се на процес његовог идентификовања с фикцијским јунацима. Други блиски рођак тромплејског читаоца стога не нестаје у свету текста већ текстуалну стварност стапа са својом. Тип погрешке који прати оваквог читаоца везан је за болест подељеног ума.

У Лазаревићевој приповеци Вериетер описује се процес идентификације (при таквом читању свака књига „говори о мени и за мене“) јунака са својим фикцијским двојником:

И што се више примицаше крају књиге, тим се све више збратимљаваше с Вертером, и најзад, кад Вертер узима пиштоље, и Јанко погледа свој револвер на зиду, који му изгледаше као некакав сигнал, и иза њега као да види боно и бледо Вертерово лице које као да му значајно клима главом: „Тако, тако, братац, ми јадни сиротани! Љубимо, али туђе жене; поштени смо, па зато треба да умремо! Ходи!" (Лазаревић 1986: 113)

Лазаревићев Јанко није само пример имерзивног читаоца који емотивно партиципира с Вертером; он фикцијског јунака „преноси“ 
у своју реалност, самерава себе према њему. Стога, на другом полу тромплејске путање, симптоми читања које је изгубило меру не манифестују се само у имерзивном интензитету (смер кретања у дубину, у текст) већ и у мери активације фикцијског у актуелном свету јунака (смер кретања у ширину, спајање текстуалног и стварносног).

Одређен тип текстова провоцира управо овакво читање. Упркос усаглашавању текстуалне и емпиријске стварности, не мислимо на аутобиографске, мемоарске текстове, документрану прозу. У овим текстовима ретроспекција усмерава нарацију; „грађа“ подлеже наративној кохеренцији готових, завршених догађаја којима се зна исход и о којима се прича. Свако препричавање истовремено је и допричавање, стварање нове приче (П. Рикер). Мислимо на други тип текстова у којима „радња“ и читаоци не претходе тексту већ га следе (аплицирају га).

\section{Читаоци-апликатори}

У овом поглављу, наши „литерарни јунаци“ су верници, они који своју реалност саображавају Кодексу (Библији, Талмуду, Курану), и све што чине тумаче кроз текст. Текст је алегорија света у коме живе, семантичко платно разастрто над сваким догађањем у њиховој физичкој стварности. Они су „фигуре“ (реализоване), апликације тог текста, оптимализоване у случајевима као што су замонашење, стигма или страдања за веру и сл.

Активирање фикцијског (попут имерзије) такође има скаларну вредност. (Иако делује да је живети текст „привилегија“ верника, на поверењу у текст почива целокупна наша цивилизација - читав низ текстова функционише по принципу апликације: уместо религиозних за душу, ту су кулинарски рецепти за стомак, медицински за тело и сл. Ми смо њихови анимирани ликови. Ова апликативна „Природа текста“ тематизована је у необичном делу Горана Петровића Саветии за лакши животи: роман уз кафу (1989).

У тромплејском свету не постоји сигурност физичког света, наративни свет није алегоријски, не постоји анестезија метафора, симбола, све је директно, не преводи се. Тромплејски читалац не живи као у тексту (богоугодно), он живи у тексту и не зна какав му пакао или рај он доноси.

Децентрирање фикционалног у поље стварносног доводи нас до друге стране читалачког ангажовања - до интерактивности и игре.

\section{Интерактивни читалац}

Иако делује да се имерзија (која подразумева „флуидност, целовитост и просторно-временски континуум“) и интерактивности 
(која претпоставља изломљену и „прозорску“ структуру“) искључују, Мери-Лор Рајан пише о сложеној пуноћи читања и њиховом „помирењу“ и „браку“ (the marriage of immersionand interactivity”) (Рајан 2001: 353). Она прати традицију интерактивног читања фокусирајући се на кључне текстове двадесетог века у којима се напуштају обрасци означавања наслеђени из деветнаестог века (Рајан 2001: 265) и с имерзивне прелази на интерактивну, додајемо, лудичку поетику (the playful nature of writing). До потпуног преокрета на скали имерзивних и интерактивних активности читалаца долази у постмодерној књижевности у којој текст престаје да се перципира дубински (урањањем) већ ризомски (ширењем у разним правцима као „врт са стазама које се рачвају“). Међу примерима текста који „провоцира“ интерактивно читање нашло се и једно од најзначајнијих дела српског постмодернизма, Павићев Хазарски речник.

У Павићев Хазарски речник улази се преко „гробља“, белине листе на којем пише: „На овом месту лежи онај читалац који неће никада отворити ову књигу. Он је овде заувек мртав.“ После фиктивног гробља нечиталаца, Павић даје прецизне инструкције интерактивном читаоцу о „начину коришћења речника“:

„Књига се може читати на безброј начина” (...) То је отворена књига и кад се склопи, може се дописивати (...) Једни ће као у сваком другом лексикону тражити реч или име које их тренутно занима, а други, књигу могу схватити као штиво које треба прочитати цело, од почетка до краја, одједном (...) читаоци могу залутати и изгубити се међу речима (...) може се читати и дијагонално (...) може се преустројавати и преметати на безброј начина као „мађарска коцка“ (Павић, 1977: 20-21).

Да би прочитао, прецизније читао Хазараски речник, читалац је требало да структуру која има (аристотеловски) почетак, средину и крај замени речником, фрагментизованим, дисперзивним исечцима, да се одрекне јединства места, времена и радње, перпетуира заплете и расплете стварајући сваким читањем нове сижејне комбинације. Читати Хазарски речнику у даху (симболички с једним „урањањем“) немогуће је чак и ако читалац прочита целу књигу у једном читању - сам текст у својој структури има прекиде (одвојене речничке јединице) и рачуна на мноштво читалачких „израњања“. Постмодернистичка демистификација текста стоји у изразитој супротности са суспензијом неверице која карактерише имерзивног читаоца који се „претвара да постоји стварност која постоји независно од језика који је ствара“ (Рајан 2001: 194).

Да бисмо боље разумели каква је сличност тромплејског читаоца с интерактивним, задржаћемо се на лудичкој поетици постмодерних романа и хипертекста. Наше разумевање тромплејског читаоца поново ће бити у знаку негација (овог пута не више у односу на имерзивног већ у односу на интерактивног читаоца). 


\section{Лудички концепт читаоца}

У књизи Иіре и льуgu: маска и занос, Роже Кајоа (Roger Caillois), један од најзначајнијих теоретичара игре, издваја неколико њених типова: agon (заснован на такмичењу), alea (на бацању коцке, игри на срећу), мимикрија (разне имитације), ilinix (игре које изазивају вртоглавицу: алпинизам, рингишпил, валцер, ход по конопцу и сл.).

Метафора игре у теоријама књижевности показала се врло продуктивном, а наведени типови послужили су нам за сликовитије сагледавање паралела између виртуелне стварности текста и читалачких искустава.

У Хазарском речнику, подсетимо се, читалац је проглашен за homo ludensa који сам саставља своју књигу-играчку .

Други тип лудичких метафора има шире значење. „Анестезирајући“ („паузирајући“) своје физичко присуство, читалац је у извесном смислу попут камелеона, неко ко се вешто мимикрира. Целокупна феноменологија почива на тој његовој невидљивој присутности, „као да“ концепту; читање тиме постаје игра одраслих блиска дечјим играма „као да сам“, „верујем да сам“. Рајанова пише да је играње луцидна активност, да играч мора „видети“кроз варљиве потезе противника и да ту луцидност мора да задржи и читалац; њему није допуштено да изгуби из вида материјалност језика: „еенна од наративних стратегија која се најчешће описује као игра је саморефлексивно, антиимерзивно метафикцијско стајалиште кроз које аутори попут Лоренса Стерна, Денија Дидроа, Флина О’Брајана или Џона Фовлеса подсећају читатеље да се баве изградњом заплета, а не самим животом“" (Rajan 2001: 194). У српској књижевности овај лудички концепт антиимерзивног метафикцијског стајалишта доследно међу првима примењује Јован Стерија Поповић у Роману без романа (1832).

\section{Тромплејски читалац versus читалац homo ludens}

Запажање Рајанове о постмодернистичком „дрском и опасном истраживању границе између естетике света и естетике игара, у којој се све може изгубити ако се граница пређе“ (Рајан 2001: 354), интерактивног читаоца је приближило његовој оптималној верзији - нашем немогућем јунаку, тромплејском читаоцу који је ту границу прешао. Разлике у односу на читаоца homo ludensa произлази из онога што се улаже у читање:

1. Тромплејски читалац у игру читања улаже сопствени живот, он се не игра камелеона, нити се претвара.

2. Његов „улазак“ (прва етапа) није праћен игром, нити је његова „виртуелна реалност“ безбедан уметнички простор. (Док је жи- 
вот читаоца неопозив, живот „улоге“ у видео-игри је опозив: улога се може поновити, прекинути, наставити, то је чини забавном.) Тромплејска реалност није забавна.

3. Тромплејски читалац је близак хипертекстуалном играчу скакачу с линка на линк. Суштинска разлика је што је његов скок у текст бесповратан. Он не може склопити књигу, не може притиснути тастер и изаћи из игре. Тиме је стигао до крајности - нарушио је правило без које игра не може (а то је да се прекине).

4. Упркос сличности етапа кроз које пролази - тромплејски читалац није лудички расположен; ако је хипертекст јединствено погодан да изрази „естетске и политичке идеале интелектуалне заједнице која је очување различитости уздигла у једну од својих основних вредности“ (Рајан 2001: 7), тромплејска реалност је суицидалан избор једне опције.

5. Другачије су и путање кретања - постмодерни хипертекстуални читалац примењује бриколаж технику, он иде одоздо, од фрагмената које повезује. Резултат је пачворк, колаж различитих елемената, оно што су Ж. Делез и Ф. Гатари назвали „машинским склопом“ („a machinic assemblage“ (Gilles Deleuze, Félix Guattari, A Thousand Plateaus, 332-35); Рајан 2001: 7). Тромплејски читалац не изражава распаднуту структуру, нестабилност вишеструких, конфликтних идентитета већ прекид, бесповратно одсуство.

6. Он није алтернатива већ крај читања. Њега не прати задовољство у тексту већ uncanny ефекат.

\section{Uncanny ефекат}

Uncanny ефекат тромплејског читања почива на онтолошком зјапу између светова. Улазак у зјап - преступ који тромплејски читалац чини - праћен је губитком, смрћу читаоца који је створио нашу писану цивилизацију.

Тромплејско читање није могућност прекида и повратка сигурном и топлом окружењу, заштићена авантура, поглед у Фиктивног Другог с безбедне онтолошке дистанце. Кроз црне рупе текста, усисан у димензије другог универзума, тромплејски читалац је с оне стране читања - у простору непознатог. Чак и кад бисмо замислили да улази у аутобиографски текст, текстуална стварност је за њега увек terra incognita јер је он Други за оног „Ја“ с којим се среће. Сваки улазак подразумева дезоријентисаност (потирање приповедачеве просторно-временске локације и ново чуло присутности околине. Кад уђе у свет дела, читалац је у простору лишеном обједињујућег значења - не постоји надређена инстанца, гарант приче, не постоји омнипотентни приповедач, не постоји омнипотентно приповедање 
јер је оно разорено упадом странца, алијана. Он је двоструки тромплеј - велика „беба“ у новом свету, оживели мртвац из старог света.

Ако је сусрет с алијанизованим светом текста увек губитак презентоцентричне позиције, саморазумљиве самоинтерпретације и опасност од себе самог (непознатог саморесетованог „ја“), зашто би онда тромплејски читалац уопште учинио преступ, напустио сигурност (прецизније, познатост) своје вантериторијалне енклаве и био у домашају ликова који би му могли нанети штету. Наслов следећег поглавља нам можда може понудити прихватљив одговор.

\section{Притисак текстуалне стварности, бекство и разрешење неподношљивог парадокса}

У поглављу Transportation and Being Lost in a Book (Преномене $u$ іудљене у књизи) задовољство невидљивог „присуств““ у свету књиге, према Рајановој, представља једно од круцијалних естетских задовољстава које прате чин читања (Рајан 2001: 97). Ово присуство почива на парадоксима емотивне партиципације, временском и просторном измештању.

„Парадокс емоционалне партиципације“ укршта искључиве активности: 1. Читалац има емоције које се односе на измишљене ситуације; 2. Да би их имао, он мора да поверује у пропозиције тих ситуација; 3. Читалац не верује у пропозиције којима се описују ситуације представљене у фикцији. (Рајан 2001: 153) Да би усагласио први и трећи корак, читалац се претвара да верује. („Концепт менталне симулације усклађује се са идејама рецентрирања, транспорта и концепта верујем $y$, али лоцирањем читаоца у центар свести ликова које он покушава разумети“" (Рајан 2001: 110). Ову врсту парадокса тромплејски читалац разрешава потпуном имерзијом у свет текста; он се потпуно предаје текстуалној стварности.

По сличном принципу тромплејски читалац разрешава и парадокс временске имерзије - он прелази у ориго тачку текста; часовници нашег света за њега престају да куцају - он проналази тренутак „сада“ у тексту из којег почиње да рачуна „јуче“, „сутра“, за два сата и сл. Он не жуди да сазна крај приче-судбине.

Пратећи читаоце на путу у текст постављамо питање где они стижу кад „прекину време“, напусте своје „физичко тело“ („одвоје се“ од себе у „каталепсичној“ позицији човека заустављеног испред екрана или нагнутог над странице књиге). Имајући на уму различитост спацијалних имерзија издвајамо два „онтолошка крајолика“ (појам смо преузели од Томаса Павела (1997: 111)) у које смештамо наше читаоце-путнике.

Пријатно место, locus amoenus, „класичног“ имерзивног читаоца, засићено је описима које читалац „препознаје“ као свој простор 
(у овим случајевима „пријатељски таласи“ (метафора урањања) кореспондирају с Башларевим метафорама куће и гнезда). Интензитет спацијалне имерзије пропорционалан је димензији „препознавања“ (већ смо помињали апсорпцијску моћ текста засновану на више или мање „засићеним“ описима, елементима који олакшавају временску и просторну имерзију; такве су нпр. референце на позната географска места и историјске догађаје). Лоцирање читатеља у центар свести ликова које он покушава да разуме, како Рајанова запажа, може бити и резултат прустовског „мадлена ефекта“ који „више зависи од случајне резонанције текста са целокупним личним сећањима него од уопштених текстуалних својстава“" (Рајан 2001: 121). Као имерзивни спацијални линкови могу се јавити приватни простори препознати у текстуалној географији (ова просторна прожимања могу се односити на мале просторе - собе, куће, радна места или се ширити на топографију улице, града, државе и сл.). Просторна имерзија се шири по принципу сличности: ми који читамо и они о којима читамо припадамо истом искуствено обликованом хуманоидном простору.

Потпуно је другачији онтолошки крајолик у који би тромплејски читалац уронио. Интерактивни простор у који улазе читаоци постмодрених романа или хипертекста, у теоријама је означен двоструко - позитивно (као отворени простор истраживања, игре, лутања, доколице) и негативно. Због сличности с нашим немогућим, хипотетичким тромплејским читаоцем, који је извршио salto mortale, и нестао из нашег логичког и искуственог читалачког хоризонта, задржаћемо се на простору који је негативно, прецизније, амбивалентно означен. Као што примећује Мајкл Хајм (Michael Heim): „Хипертекстуално размишљање заиста може открити нешто о нама што је узнемирено, панично или чак патолошко. Како ум скаче, и психа постаје скакутава или „хипер“ (Неim 1993: 40, Рајан 2001: 261).

Уколико код тромплејског читаоца изостане спацијална имерзија (тј. минимализује се), тј. уколико он урони у текст у коме не може да оствари блискост с текстуалним простором, он постаје попут читаоца хипертекста, номад изгубљен у обескорењеном окружењу.

\section{Постмодерни, хипертекстуални номади и тромплејски скакач}

Тромплејски читалац нестао у тексту своје непосредне претке нема у читаоцима класичних реалистичких романа. Од њих је наследио имерзивни „мем“9 (и радикализовао га, мутирао - он удара о дно

9 Полазећи од идеје да је преношење културе аналогно преношењу гена (199) у књизи Себичан іен Ричард Докинс користи појам мем да означи јединицу преношења културе, или јединицу имитације. Мем-идеје дефинише као целине која су у стању да се пренесе од једног мозга до другог. „Кад умремо“, пише Докинс, „за собом остављамо гене и меме“" (Докинс: 2014: 209). 
и заузима место на најдубљем подеоку скале; његова просторна имерзија је апсолутна чиме престаје игра претварања јер се његово физичко биће трансформише у текстуално). Његови непосреднији преци су читаоци постмодерне и још ближи - читаоци хипертекста. Њихова искуства света - њихов нов доживљај простора (света као места који није благонаклоно човеку) развија ескапистички мем, по нашем мишљењу пресудан за профилизацију тромплејског читаоца - оног који је пожелео да нас заувек напусти (поразна статистика зависника од видео-игара упућује на рани стадијум и развијеност овог мема).

Да бисмо разумели из којег света тромплејски читалац бежи у свет текста - задржаћемо се на неколиким карактеристикама новог „хуманодиног“ простора.

Тромплејски читалац је онај који акумулира „негативно искуство“" свог постмодерног претходника, номада суоченог с не-местима (Оже), глатким простором (Делез), кретањем у лавиринту (Џејмсон), дељивим, савитљивим, катастрофичним простором (Кристева). Излаз из просторног лавиринта проналази у препуштању једној наративној опцији - скоку у текст. Он је фигура реализованог парадокса, интерактивно имерзивни читалац, крајност читања која се потиру у свом максимуму.

\section{А шта је с телом?}

Шта се дешава с нашим телом док читамо? Иако делује да је читање кататоничан чин умртвљеног тела избаченог из стварности (уроњеног у виртуелно), тело је ипак ту. Ма колико оно било невидљиво за свет у који урања, оно се „удваја“ (читалац има дупло тело: физичо и виртуелно - Witmer, Singer,1998: 226).

Имајући на уму корпоралну (често игнорисану) димензију читања, Мери-Лор Рајан сматра да је илузија погрешан појам за означавање нечега што она назива „средње свесно урањање“ (mediumaware immersion): „Иако се термин илузија широко користи за описивање реакције на реално представљање, то је заиста погрешан назив. Осим неких патолошких случајева углавном документованих помоћу имагинарних ликова - уобичајених осумњичених, Еме Бовари и Дон Кихота - корисници медија остају потпуно свесни размишљања о репрезентацији, чак и кад се та репрезентација чини стварнијом од живота“ (Рајан 2001: 352).

Патолошки случајеви које Рајанова узгред помиње и о којима пише углавном као плоду фикције су наш путоказ у свет тромплејског читаоца. Они су његови директни дезоријентисани рођаци изгубљени у онтолошком зјапу текстуалне и физичке (емпиријске) стварности. Тромплејски читалац отклања њихов напор да гледају у вртоглав понор расцепљених светова - скоком у један. 


\section{Кад грешка постане лик}

У књижевности постмодерне читалац-грешка постао је литерарна тема. Навешћемо два примера. Први је из светске, а други из српске књижевности.

У приповеци Конитинуитетет йаркова (Continuidad de los parques), Хулио Кортасар развија врло сложен тромплејски наратив у којем сви јунаци чине преступ - они струје кроз две онтолошке равни без икаквог отпора. У исто време су јунаци текста, и јунаци „ван текста“. Лик-читалац док чита постаје јунак приче коју чита. Сиже приче која га је заинтересовала (љубавник и љубавница припремају убиство њеног супруга), неуобичајеним расплетом, постаје његова биографска прича; муж-жртва је заправо читалац који се сваким прочитаним редом приближава сопственој смрти. Мала детективска прича се ствара у онтолошком зјапу у којем је сам читалац жртва убиства чију припрему с читалачком знатижељом пажљиво прати. Крај читања је крај приче и крај живота. Наративни суспенс, климакс, све се сустиче у завршетку приче која губи (усмрћује) свог читаоца. Не постоје оквирни облици, дијегетички нивои, сва наративна правила нестају у геометрији коцке којом смо симболично отворили наш текст.

Други пример су ликови читаоци из романа Горана Петровића Сийничарница Коg срећне руке. Пар који се у стварности не препознаје, среће се на страницама књиге коју чита. Иако исто биће,живи“" „ „иита“, не постоји тачка „онтолошког ослонца“ која би предност дала физичкој над текстуалном стварношћу у којој им се дешава љубав. Сусрети се заказују у описима и љубавна романса развија сваким прочитаним редом - граница између виртуелног и актуелизованог је потпуно замагљена (слично бивалентном онтолошком стању Павићевих јунака који живе сан и сањају живот).

У Кортасаровој и Петровићевој нарацији нарушен је имерзивни парадокс који чува стабилност онтолошких нивоа на којем почива класичан наративни текст. Тиме су неповратно дестабилизовани дијегетички нивои приповедања и виртуелном нарацијом поништене бинарне опозиције између актуелног и виртуелног. У обе приче „онтолошки колапс“ настаје о-стварењем немогућег (у тексту се живи, воли, убија); као у стварању света, дешава се реч а ту нема простора за металепсу.

Кортасарова прича и Петровићев роман примери су сложених фигура у којима се укрштају путање тромплејских јунака. На размеђу две опречне силе - једне центрифугалне која их увлачи у свет текста и друге центрипеталне која текст увлачи у њихов свет. Они су двоструки тромплеји: а) читаоци које су прешли немогућу границу и ушли у текст, б) ликови који су прешли немогућу границу и изашли из текста. 
Ипак, упркос сложености, и они су (попут Сремчевих попадија, или Лазаревићевог Јанка) „само“ литерарни јунаци - становници текстуалне стварности. Завршни део рада посвећујемо футуристичкој пројекцији тромплејског читаоца који није „литерарна тема“, који је престао да буде тромплеј (превара) и постао наша антиципација будућег читаоца. Ако бисмо тражили неку врсту теоријског оправдања за његову експликацију, за научну фантазију којом завршавамо наш рад, нашли бисмо је у Епштејновој алтернативној трансформативној хуманистици (The Transformative Humanities 2012) која својом потенцијалношћу одговара духу кибернетичког доба и уз политику и технику активно учествује у креирању новог света.

\section{Кад теорију о читаоцу замени фантазија о летећим рибицама}

Поменули смо да примарну мотивацију за тромплејски скок у другу (виртуелну) реалност (за судбоносни прекид с нашом традицијом добро избалансираног имерзивно-интерактивног читања) препознајемо у неиздрживом притиску текстуалне стварности. Ако је скок у ту стварност плод наших фантастичних спекулација, сам притисак није, он је реалност која се већ осећа. Експлозија писма је у Деридиној Грамайолоіији била најављена још 1967. Да бисмо указали на моћ писаног пре дигиталне ере, као симболичку илустрацију бирамо приповетку Иве Андрића написану давне 1924.

У приповеци На gруіи gан Божића описује се кошмар који јунак „умирује“ провером свог „будног“ идентитета. Иако се јунак у сну налази у непознатом граду, простор му је познат; уобичајени дан конзула у канцеларији дат је у ониричкој инверзији; конзул је с друге стране себе: он је онај који моли, који нема документа и који чује себе из стварности преко пута себе из сна као Неосетљивог Одбојног Другог; У истом бићу стварност се растаче: ушушкана стварност под љубичастим јорганом - насупрот стварности човека без докумената у студеном дворишту. Лиминална позиција онтолошки неопредељеног бића (ониричког и стварног) прекида се отварањем фиоке и трагањем за писаним трагом о себи: „Све је ту: од матурске сведоџбе, па до последњег указа којим се поставља за генералног конзула прве класе“ (Андрић 2017: 71). Писани траг о себи постаје гарант „праве стварности“, моћно средство подвојеног бића које истинског себе, до чије спознаје стиже у сну, замењује својом социјалном маркацијом.

Ова дигресија има за циљ да укаже на све агресивнији текстуални универзум који постоји паралелно с нама. Иако мислимо да бирамо шта ћемо читати, већина текстова нам је наметнута. Школска лектира, награде, спискови најпопуларнијих књига, рекламе - читалачке су мишоловке које не можемо избећи. Још су боље поставље- 
не у дигиталном простору. Читалац хипертекста сваким линком означава своје присуство, маркира интересовања, постаје „кош“ за слично које се генерише сваким следећим кликом. Компјутер чита њега, а линкови и хипертекстови постају попут менталног крвотока. Век после Андрићеве приповетке, модерни homo ludens се нашао пред новим парадоксом: иако делује да је суочен са слободом избора у безмерју текста, он је заправо њиме заробљен, убачен у комбинаторику текстова - од оних које слуша у вртићу до оних које генерише (који га генеришу) на рачунару. У електронској комуникацији већ је скован појам који открива нашу изгубљеност у текстуалном универзуму, лутање и насумичне поготке (serendipity означава случајно откриће текста на интернету иако смо почетно кренули од другог линка и повезали се с другим текстом). Сведочанства, пасворди, идентификационе, платне картице постали су наше највалидније „ја“. Као у Андрићевој причи - „највећа реалност“, облик идентитетског самоспознавања у којој је свака комуникација (са собом, с другим) замењена регистрацијом.

Какав текст ће нас бирати у будућности? И да ли ћемо моћи да избегнемо замку Мреже и задржимо тело-гнездо, да се одупремо сиренским гласовима Великог Текста?

У страху од непознатог Великог Текста, прибегавамо новој метафори. Воденим метафорама Мери-Лор Рајан придајемо метафору летеће рибице. Метафора се појавила случајно (serendipity). Наш футуристички читалац ће имати све вештине урањања, понирања у дубину, и израњања, летења у висину. Ма колика ескапистичка примордијална жеља тромплејског читалаца била у њему, он неће извршити salto mortale. Остаће у свом телу-свету (попут нас старовременских читалаца) без обзира на то кроз који свет-текст се кретао. Једноставно, биће летећа рибица.

\section{ЛИТЕРАТУРА}

Андрић 2017. Андрић, Иво. Приче. Београд: Лагуна.

Appleyard1991: J. A. Appleyard, Becoming a reader, The Experiance of Fiction from Childhood to Adulthood, Cambridge Universtity Press.

Bart, Rolan. Književnost, mitologija, semiologija. Preveo Ivan Čolović. Beograd: Nolit 1971.

Bart, Rolan. „Smrt autora“. U: M. Beker (ur.). Suvremene književne teorije. Zagreb: SNL 1986, 176-180.

Бојанић Ћирковић Мирјана: Тийолоїја чийалаца у романима Ми-

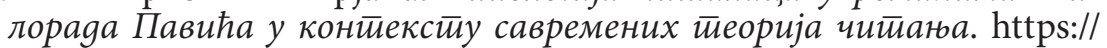
fedorani.ni.ac.rs/fedora/get/o:1490/bdef:Content/get

Болтер 1991: Bolter, Jay David, Writing Space: The Computer, Hypertext, and the History of Writing. Hillsdale, N. J.: Lawrence Erlbaum, 1991. 
Вукићевић, Драгана 2015, Скривени нарайиви, У: Зборник Матице српске за књижевност и језик, књ. 63, св. 2, 505-519.

Грчић Миленко, Јован. У Госитионици Код полузвезде на именgан иан-

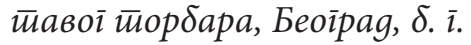

Докинс 2014: Ричард Докинс Себичан іен, Смедерево: Хеликс.

Женет 1985: Genette, Gérard: Мотивација и вероватноћа, У: Фиі̄pe, Београд, Вук Караџић.

Изер, Волфганг „Lutajuće motrište i čitateljska svijest“. Biti, Vladimir (prir.), Suvremena teorija pripovedanja. Zagreb: Globus 1992, 158-177.

Jayc 1978: Jaus, Hans Robert. Estetika recepcije. Prevod Drinke Gojković. Beograd: Nolit

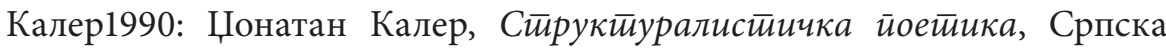
књижевна задруга.

Kajoa 1965: Roger Caillois, Igre i ljudi: maska i zanos Beograd: Nolit.

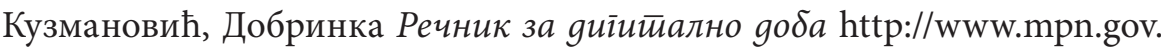
rs/wp-content/uploads/2020/03/Recnik-za-digitalno-doba.pdf прегл. 27.06.2020.

Лазаревић 1986: Лазаревић Лаза Прийовейке, Београд, САНУ.

Милосављевић Милић, Снежана, Фиіуре читиаюа. Београд: Службени гласник 2013.

Обрадовић Доситеј, 2009, Животи и ӥрикљученија, http://www. antologijasrpskeknjizevnosti.rs/ASK_SR_AzbucnikPisaca.aspx, прегл.27.06.2020.

Павел 1997: Т. Павел, Фикиионални свет̄ови и еконимија имаїинарної, Реч, 30, 111.

Павић 1976: М. Павић, Језичко йамћене и иеснички облик, Нови Сад: Матица српска.

Павић 1977: Милорад Павић, Хазарски речник, Београд: Дерета, Просвета

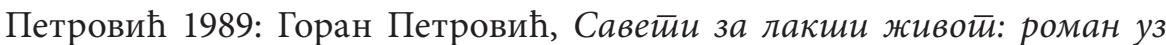
кафу, Књижевна омладина Србије.

Рајан 2001: Ryan, Marie-Laure, Narrative as Virtual Reality Immersion and Interactivity in Literature and Electronic Media, The Johns Hopkins University press, Baltimore and London.

Routledge Encyclopedia of Narrative Theory by David Herman, Manfred Jahn and Marie-Laure Ryan (eds), 2008. London and New York:

Ruse, Žan. „Da li je potrebno govoriti o 'narateru'?“. U: Kako ukrotiti tekst. Prir. dr Slavica Perović. Podgorica: Institut za strane jezike - Oktoih 1999, 413-423.

Сремац 2009, Сремац Стеван Пой Ћира и йой Сūupa http://www.antologijasrpskeknjizevnosti.rs/ASK_SR_AzbucnikPisaca.aspx, прегл. 27. 06. 2020.

Стојановић 2009: Јасна Стојановић, Досийеј и Серванйес, Научни састанак слависта у Вукове дане, 38, 2009, св. 2, 529-536.

Рикер 1993: Пол Рикер, Време и иррича, IK Zorana Stojanovića, 1993. 
Рифатер 1990: Референцијална илузија, Трећи програм, 85, 196-202.

Хавелок Е. 1991: Муза учи ga йчше, прев. Г. Кркљуш, Нови Сад, Светови. Хајм 1993: Heim, Michael. „The Erotic Ontology of Cyberspace.” Benedikt, Cyberspace, 59-80. The Metaphysics of Virtual Reality. New York: Oxford UP, 1993.

Štirle, Karlhajnc. „Čitanje fikcijskih tekstova“. Književna kritika, god. 20, br. 9, 1989, 61-74.

Witmer, Bob G., and Michael J. Singer 1998: „Measuring Presence in Virtual Environments: A Presence Questionnaire." Presence: Teleoperators and Virtual Environments 7, no. 3 (1998): 225-40.

Dragana Vukićević

The Impossible Trompe L'Oeil Reader and his Cousins

\section{Summary}

The paper starts with the study of Marie-Laure Ryan Narrative as Virtual Reality. Hertypology of theimmersiveand interactive reader is revised by the anticipation of the hypothetical trompley (trompel' oeil) reader. He is explained through comparisons of similarities and differences in relation to the addicted reader who is often subject of referential or affective misconceptions. The second type of differentiation, in the virtual world of electronic media, is established in relation to the concept of the game by Roger Caillois and his equating reading with mimicry games. We follow genesis of reader from the conceptualization of Don Quixote syndrome reader, precedes the fake reader (the protagonist of postmodernist prose of Cortázar, Borges, Pavić, Petrović) to the anticipation of trompe l' oeil-reader.

Keywords: trompe l' oeil, immersion, interactive reader, addicted reader

Примљено: 15. 2. 2020.

Прихваћено: 30. 7. 2020. 